Marek Augustyn OFMConv, Dalmatyka - historia jej wprowadzenia do liturgii i znaczenie, w: Szata liturgiczna, red. Adelajda Sielepin CHR, Jarosław Superson SAC, Kraków 2016, s. $7-15$.

DOI: http://dx.doi.org/10.15633/9788374386029.02

Marek Augustyn OFMConv

\title{
Dalmatyka - historia jej wprowadzenia do liturgii i znaczenie
}

\section{ZWYCZAJE W PIERWOTNYM KOŚCIELE}

Żyjący na przełomie II i III wieku n.e. łaciński apologeta chrześcijański Marek Minucjusz Feliks napisał, że chrześcijanie nie mają ,,ani świątyń, ani ołtarzy". Powszechnie interpretuje się powyższe słowa jako potwierdzenie faktu, że w Kościele pierwotnym wyznawcy Chrystusa, czy to jeszcze w Palestynie, czy potem w kulturze grecko-rzymskiej, nie odróżniali się od innych obywateli. Słowa te świadczą ponadto o dużej świadomości potrzeby duchowego kultu, do jakiego zresztą zachęcał sam Jezus, choćby w rozmowie przy studni z Samarytanką. Jezus powiedział jej wówczas:

Wierz Mi, kobieto, że nadchodzi godzina, kiedy ani na tej górze, ani w Jerozolimie nie będziecie czcili Ojca. Wy czcicie to, czego nie znacie, my czcimy to, co znamy, ponieważ zbawienie bierze początek od Żydów. Nadchodzi jednak godzina, owszem już jest, kiedy to prawdziwi czciciele będą oddawać cześć Ojcu w Duchu i prawdzie, a takich to czcicieli chce mieć Ojciec. Bóg jest duchem; potrzeba więc, by czciciele Jego oddawali Mu cześć w Duchu i prawdzie (J 4, 2I-24).

Takie podejście do spraw wiary spowodowało specyficzną sytuację. Chrześcijanie, żyjąc w świecie, nie odróżniali się zewnętrznie od pogań- 
skiego otoczenia, ale przemieniali ówczesny świat swoją wiarą i zasadami życia. Stąd w Liście do Diogneta pochodzącym z II wieku czytamy, że

chrześcijanie nie odróżniają się od innych ludzi ani jakimś specjalnym terytorium, ani językiem, ani zwyczajami. Nie zamieszkują osobnych miast, nie mają własnego języka, nie prowadzą jakiegoś osobliwego trybu życia [...]. Mieszkają w miastach zarówno greckich, jak i barbarzyńskich, jak komu wypadnie [...]. Mieszkają w swojej ojczyźnie, ale jakby byli cudzoziemcami; wykonują wszystkie obowiązki dobrego obywatela i nie uchylają się od żadnych ciężarów, ale czynią to jakby byli przyjezdnymi gośćmi. Każda obca ziemia jest dla nich ojczyzną, każda ojczyzna jest dla nich obcą ziemią [...]. Żyją na tej ziemi, ale czują się obywatelami nieba. Są posłuszni ziemskim prawom, ale ich sposób życia wynosi ich ponad wszelkie prawor.

Św. Paweł Apostoł pisząc do Koryntian, wspomina jednak o kontynuowaniu na zgromadzeniach pewnych tradycji, np. zwyczaju modlenia się przez mężczyzn z odkrytą głową, a w przypadku niewiast przeciwnie - z nakrytą głową. To może być świadectwem zachowywania od początku pewnych norm i przepisów.

Na podstawie tego, co wyżej powiedziano, można śmiało stwierdzić, że chrześcijaństwo starożytne nie znało specjalnych strojów do sprawowania liturgii.

O miejscu i roli człowieka w liturgii nie decydowała bowiem zewnętrzna szata, ale miejsce, jakie zajmował w zgromadzeniu².

Do okresu średniowiecza istniało przekonanie, że szaty liturgiczne zostały zapożyczone od kapłanów ze Starego Testamentu, że były wzorowane na szatach, które przepisał im Mojżesz dla posługi kultycznej w świątyni. Dzisiaj natomiast powszechnie przyjmuje się, że szaty liturgiczne wywodzą się od szat codziennego użytku noszonych przez starożytnych Greków i Rzymian. Te same szaty, które służyły ludziom w życiu codziennym, miały swoje zastosowanie także podczas sprawowania liturgii³. Stopniowo rodziła się świadomość, że do sprawowania czynności najświętszych nale-

1 Do Diogneta, V, 5-6, w: Pierwsi świadkowie: Pisma Ojców Apostolskich, thum. A. Świderkówna, oprac. M. Starowieyski, Kraków, s. 339-348 (Biblioteka Ojców Kościoła, Io).

2 P. Greger, Szata stużby liturgicznej w Kościele w Polsce. Próba propozycji, „Anamnesis” 4I (2005), s. I00-I08.

3 Leksykon liturgii, red. B. Nadolski, Poznań 2006, s. I505. 
żałoby zakładać odzież świąteczną. Być może więc szaty używane do sprawowania „łamania chleba” były zarezerwowane jedynie do celebrowania Eucharystii. Wiemy jednak, że papież Celestyn I (422-432) zakazywał prezbiterom używania w czasie celebracji innych szat niż codzienne. Szybko jednak pojawiły się głosy, aby do sprawowania liturgii stosować szaty najpiękniejsze, białe, chociaż posiadały one taki sam krój jak stroje używane na co dzień ${ }^{4}$.

\section{Historia dalmatyki}

Diakoni podczas liturgii pierwotnie przywdziewali szatę zwaną „colobium”5. Była to krótka, sięgająca do kolan lniana tunika bez rękawów. Rzymianie ubierali tego rodzaju szatę dowykonywania rozmaitych prac w gospodarstwie domowym. Brak rękawów sprzyjał pracy rąk. Być może później zastąpiono tę szatę przez dalmatykę - długą szatę lnianą, z krótkimi i bardzo szerokimi rękawami, ozdobioną dwoma czerwonymi, biegnącymi od góry do dołu, z przodu i tyłu, pasami „clavi”, które miały zasłonić nie do końca zakryte przez „colobium” ramiona. Dalmatyka zawdzięcza swą nazwę krainie, z której pochodzi - Dalmacji. W Rzymie szata ta została wprowadzona ok. II wieku i była noszona przez osoby z wyższych klas?

Początkowo uważano dalmatykę za szatę bardziej przydatną niewiastom $i$ to do tego stopnia, że przywdziewana przez mężczyzn wywoływała nawet zgorszenie ${ }^{8}$. Szybko jednak uznano ją za szatę zaszczytną; używała jej

\footnotetext{
4 S. Araszczuk, Wplyw tradycji rzymskich na rozwój liturgii Kościoła, „Perspectiva. Legnickie Studia Teologiczno-Historyczne" XIV (20I5), s. 9.

5 M. Bussagli, G. Babic, Abbigliamento liturgico, w: Enciclopedia dell'Arte Medievale (I99I), http://www.treccani.it/enciclopedia/abbigliamento-liturgico_(Enciclopedia-dell'Arte-Medievale (I9.0I.20I6).

6 „Debet autem dalmatica habere duas lineas coccineas, hinc inde, ante et retro, a summo usque deorsum". Innocenty III, De sacro altaris mysterio, libri VI, caput XL, PL CCXVII, 789.

7 Isidoro di Siviglia, Etymologie, PL LXXXII, 685.

8 S. Piccolo Paci, Storia delle vesti liturgiche. Forma, immagine e funzione, Milano 2008, s. 322.
} 
arystokracja, zwłaszcza podczas ceremoniału dworskiego. Dalmatyka była także strojem konsekracyjnym królów ${ }^{9}$.

Strój cywilny i szaty liturgiczne były w zasadzie jednakowe aż do VI wieku. Dopiero kiedy nastąpiły spore zmiany cywilizacyjne, moda świecka ulegała szybkiej zmianie, natomiast szaty służące do sprawowania świętych czynności pozostały niezmienione ${ }^{\mathrm{I}}$.

W Kościele pierwotnym, zwłaszcza w okresie prześladowań, męczenników grzebano w dalmatykach. Zwyczaju tego zabroniono dopiero po synodzie rzymskim w 595 roku $^{\mathrm{II}}$.

W rzeczywistości przejście od stroju świeckiego do szaty liturgicznej dokonało się w długim okresie wzajemnych relacji pomiędzy władzą cesarską a duchowną. Dalmatyka do garderoby papieża weszła prawdopodobnie za zgodą cesarza. Papież z kolei zezwolił nosić ją biskupom. Papież św. Sylwester (3I4-335) wydał pozwolenie, aby także diakoni rzymscy zakładali dalmatykę podczas liturgicznej posługi ${ }^{12}$. Cesarz wschodni zaś pozwolił nosić dalmatykę patriarchom Konstantynopola.

Dzięki listom Grzegorza Wielkiego (z lat 590-604) możemy poznać szczegóły dotyczące trzech elementów ubioru, który nie był powszechnie stosowany w Kościele. Są to: dalmatica, mappula i pallium. Inny dokument, anonimowy manuskrypt o niejasnej dacie powstania, wymienia elementy stroju używanego w Kościele gallikańskim. Są to: pallium, casula, manualia, vestimentum, alba oraz stola ${ }^{\mathrm{I}}$. Dalmatyka była strojem noszonym początkowo przez biskupów, kapłanów i gdzieniegdzie diakonów. Dopiero gdy wszedł do użytku i bardzo szybko rozpowszechnił się ornat, dalmatykę zakładali jedynie diakoni. W późniejszych wiekach noszenie jej pod ornatem pozostało przywilejem. Jeszcze w VIII wieku dalmatyka była szatą używaną wyłącznie w Kościele rzymskim. Co więcej, można ją było nosić jedynie za specjalnym zezwoleniem Stolicy Apostolskiej. Dopiero po soborze trydenckim została przypisana do stroju pontyfikalnego biskupa ${ }^{\mathrm{I}}$.

S. Piccolo Paci, Storia delle vesti liturgiche..., dz. cyt.

10 S. Araszczuk, Wplyw tradycji rzymskich ..., dz. cyt., s. Io.

11 S. Piccolo Paci, Storia delle vesti liturgiche..., dz. cyt., s. 324.

12 S. Piccolo Paci, Storia delle vesti liturgiche..., dz. cyt..

13 M. Wendland, Geneza i symbolika szat kapłańskich, „Christianitas” 53-54 (2013), s. 38I.

14 M. Wendland, Geneza i symbolika szat kaptańskich, dz. cyt. Jednakże cytowana wcześniej Sara Piccolo Paci twierdzi w swojej pracy, że już od IX wieku dalmatyka była używana przez biskupów i kapłanów, a od XI wieku było to już zjawisko powszechne. 
Biskupi przywdziewali dalmatykę pod ornat. Była ona zatem spodnią szatą liturgiczną.

W zbiorach muzealnych Fundacji Antonio Ratti w Como we Włoszech znajduje się zachowany fragment materiału z pięknym krzyżem utkanym z żółtych, czerwonych, różowych i czarnych nici, z greckim napisem. Jedna z hipotez dotyczących owej tkaniny sugeruje, że może to być część dalmatyki kapłańskiej z okresu pomiędzy X a XIV wiekiem ${ }^{15}$.

\section{KSZTAET I SYMBOLIKA ${ }^{16}$ DALMATYKI}

Pierwotnie używane białe i proste dalmatyki miały symbolizować świętą i nieskalaną religię. Tak tłumaczył prosty krój i biel dalmatyki Amalariusz z Metz ${ }^{17}$. Ponadto biel dalmatyki odnosi się także do niewinności i czystości tych wszystkich, którzy przywdziewają dalmatykę i oddają się służbie bliźnim. Papież Innocenty III (zm. I2I6) dodaje jeszcze, że dalmatyka ze względu na swoją obszerną, szeroką formę symbolizuje również miłosierdzie Chrystusa ${ }^{18}$. Stąd też dowiadujemy się, że na przełomie XII i XIII wieku dalmatyka miała jeszcze duże rozmiary. Dalmatyka była zatem traktowana jako szata służebna, dlatego też biskupi przywdziewali ją pod ornat. Kiedy podczas liturgii w Wielki Czwartek umywali nogi bliźnim, zdejmowali ornat, pozostając w dalmatyce ${ }^{19}$. Jedyną ozdobą pierwotnych dalmatyk były wspomniane już dwa pionowe pasy (clavi), najczęściej koloru czerwonego. Kolor dalmatyki zaczął się zmieniać w epoce karolińskiej. Natomiast od przełomu XII i XIII w. istniały już ścisłe kanony dotyczące kolorów, zwłaszcza kolorów szat kapłańskich. Kanony te wprowadził papież Innocenty III, kiedy podjął reformę liturgiczną, zwaną powszechnie reformą liturgii kurii rzymskiej. Z czasem zaczął się zmieniać również krój dalmatyki. Z szaty szerokiej przemieniła się w szatę węższą, z otwartymi bokami, aby nie krępować za bardzo

\footnotetext{
15 S. Piccolo Paci, Storia delle vesti liturgiche ..., dz. cyt., s. 324.

16 Informacje na temat symboliki szat liturgicznych w ogóle znaleźć można w: P. Greger, Szata stużby liturgicznej..., dz. cyt..

17 A. di Metz, De ecclesiasticis officis, caput XXI, De dalmatica, PL CV, I096-I097.

18 Innocenty III, De sacro altaris mysterio, libri VI, caput XL, PL CCXVII, 789.

19 S. Piccolo Paci, Storia delle vesti liturgiche..., dz. cyt., s. 322.
} 
ruchów noszącego szatę. Najprawdopodobniej również od tego czasu zaczęto zastępować oryginalną wełnę, jaka była pierwotnie używana do wyrobu dalmatyk, przez nowocześniejsze i będące w modzie len i jedwab.

Od XIV wieku stosowano rękawy odpinane, które utrzymywały się na ramionach za pomocą kolorowych wstążek. $Z$ czasem zaniknął również zwyczaj przyozdabiania dalmatyk pionowymi pasami. Do zdobienia szaty używano coraz częściej złota. Sposób ozdabiania szat także zaczyna się różnić w zależności od regionu i kultury, w której szata powstaje. Wykształcił się w ten sposób wzór włoskich dalmatyk z bardziej ozdobnym dolnym fragmentem dalmatyki. Inny zgoła był styl francuski, gdzie bardziej ozdobną częścią była okolica szyi. Jeszcze inny styl powstał w Niemczech, gdzie ozdabiano nade wszystko plecy.

Poza tym dalmatyka diakońska różniła się od tej zakładanej przez subdiakonów. Ci drudzy mieli szatę z dłuższymi i bardziej wąskimi rękawami. Modyfikacjom podlegały także rozmiary dalmatyk. Poza Włochami, w innych regionach Europy, zaczęto stosunkowo szybko skracać dalmatyki. W Italii nastąpiło to dopiero w XVI wieku.

Papież Innocenty III dodawał, że dalmatyka, zwłaszcza dalmatyka używana przez biskupa, po swej lewej stronie powinna być zakończona koronkami. Koronki miały podkreślać aktywną służbę ludowi ${ }^{20}$.

Pomiędzy XVI a XVIII wiekiem zaczęto przyozdabiać dalmatyki rozmaitymi symbolicznymi dekoracjami.

Wraz z wykształceniem się ceremoniału biskupiego dalmatyka stała się lekką spodnią szatą biskupów, nakładaną na tunikę. Tunika, dalmatyka i ornat zakładane przez biskupa miały symbolizować pełnię kapłaństwa i najwyższy stopień w hierarchii w Kościele.

Dalmatyka występuje również w rycie wschodnim. Nazywana jest tam sakos. Była używana rzadko, według niektórych źródeł tylko trzy razy w roku: na Wielkanoc, Boże Narodzenie i Zesłanie Ducha Świętego. Wschodnie sakos to krótka tunika, z rękawami albo bez. Część przednia i plecy połączone są ze sobą za pomocą guzików albo tasiemek. Szata wschodnia często jest przyozdobiona krzyżem na plecach.

20 Innocenty III, De sacro altaris mysterio, libri VI, caput LVI, PL CCXVII, 795, za: S. Piccolo Paci, Storia delle vesti liturgiche..., dz. cyt., s. 325. 


\section{AKTUALNE PRZEPISY LITURGICZNE DOTYCZĄCE DALMATYKI}

Ogólne wprowadzenie do Mszału rzymskiego ${ }^{21}$ (OWMR) w numerze 338 stanowi: „Szatą własną diakona jest dalmatyka, którą wkłada na albę i stułę; gdy dalmatyki brak lub gdy obrzędy są sprawowane mniej uroczyście, diakon może jej nie wkładać".

Oprócz sprawowania posługi podczas mszy św. diakon może również założyć dalmatykę, kiedy przewodniczy sprawowaniu Liturgii Godzin. Ogólne wprowadzenie do Liturgii Godzin ${ }^{22}$ (OWLG) w rozdziale V, dotyczącym zachowania się podczas oficjum odprawianego w chórze lub wspólnie, w numerze 255 mówi: „Kapłan lub diakon przewodniczący odprawianiu oficjum może się ubrać w albę albo komżę i stułę. Ponadto kapłan może również użyć kapy. W większe uroczystości kilku kapłanów może się ubrać w kapy, a diakoni w dalmatyki".

Dalmatyka jest także przywdziewana przez biskupa.

Gdy biskup odprawia w sposób uroczysty, powinien używać dalmatyki, zgodnie z dawną tradycją. Ponadto winien jej używać także we mszy św. czytanej: w czasie konsekracji biskupa, przy udzielaniu święceń, benedykcji opata i przyoryszy, przy błogosławieństwie i konsekracji dziewic, w czasie konsekracji kościoła i ołtarza. Jednakże dla słusznej przyczyny może nie wkładać dalmatyki pod ornat ${ }^{23}$.

Wskazania związane z posługą liturgiczną biskupa skodyfikowane zostały w specjalnej księdze, która nosi łacińską nazwę Caeremoniale episcoporum $^{24}$. Ceremoniał podaje, iż biskup podczas liturgii używa takich samych szat jak prezbiter, wypada jednak, aby z okazji uroczystych celebracji zgodnie z tradycyjnym zwyczajem pod ornat nakładał dalmatykę, która zawsze może być biała. Szczególnymi okazjami wymienionymi przez księgę

\footnotetext{
21 Cytat za: Ogólne wprowadzenie do Mszału Rzymskiego. Z trzeciego wydania Mszału Rzymskiego, Rzym 2002, Poznań 2004.

22 Cytat za: Liturgia Godzin zakonów franciszkańskich w Polsce, t. I, Wrocław 2013.

${ }_{23}$ Instructio „De ritibus et insignibus pontificalibus simplicioribus reddendis”, n. I7, AAS 60 (1968), s. 409.

24 Caeremoniale episcoporum. Ex decreto Sacrosancti Oecumenici Concilii Vaticani II instauratum auctoritate Ioannis Pauli II promulgatom. Editio typica (reimpressio emandata), Città del Vaticano 2008.
} 
jest udzielanie święceń, błogosławieństwo opata i ksieni oraz poświęcenie kościoła i ołtarza ${ }^{25}$.

Tak więc co do dalmatyki i jej używania w liturgii, to jest ona szatą zewnętrzną diakona i powinna być przez niego używana przynajmniej podczas uroczystych liturgii. Nie jest jednak obligatoryjna. Podobnie używanie dalmatyki nie jest konieczne w przypadku biskupów, chociaż z cytowanych przepisów widać, jak mocno jest zalecana, zwłaszcza podczas niektórych ważniejszych celebracji. Wydaje się, że przepisy dotyczące używania dalmatyki tak przez diakona, jak i biskupa są wyrażone raczej językiem niezbyt mocnym („może założyć”, „powinien używać” albo „może nie wkładać”). Być może to jest przyczyną faktu, że najczęściej szatę tę spotkać możemy w kościołach katedralnych lub seminaryjnych. Rzadziej zaopatrzone dalmatyki są w zakrystie naszych kościołów parafialnych. Zważywszy, że II Sobór Watykański przywrócił w Kościele pradawną, bo sięgającą czasów apostolskich, instytucję diakonatu stałego, a Kościół w Polsce, poprzez decyzję Episkopatu, z początkiem roku 2004 zatwierdził stały diakonat, można mieć nadzieję, że w celebracjach uroczystych liturgii będziemy mieli częściej do czynienia także z dalmatyką.

Na zakończenie warto przytoczyć piękną myśl ks. Bogusława Nadolskiego, który w Leksykonie symboli liturgicznych stwierdza, że szaty liturgiczne to nie ubiór teatralny. Piękne szaty liturgiczne mają uświadamiać uczestnikom liturgii, że biorą udział w misterium wiary i powinny ułatwiać ludziom zachwyt atmosferą uwielbienia Boga. Poszczególne szaty są wykonywane nie dla podkreślenia walorów osoby, lecz po to, by stworzyć przestrzeń dla Chrystusa, który jest pierwszym Liturgiem, mają ułatwić uchwycenie sensu sprawowanego misterium. Ogólnie można stierdzić, że szaty są dla podkreślenia wielkości i świętości Boga, mają przysłonić sprawującego i pozwolić mu na całkowite oddanie się na służbę Chrystusowi ${ }^{26}$.

25 Caeremoniale episcoporum, 56.

26 Szaty liturgiczne, w: B. Nadolski, Leksykon symboli liturgicznych, Kraków 20I0, s. 294. 


\section{SUMMARY}

At the beginning of the Church, the Christians had not differed from others in terms of clothing. What is worth noting, that during the first liturgies there was no special religious attire used. Not a piece of garment decided about the position and role of a man in the liturgy but the stance among the congregation. As the time passed by, unique clothing known as vestments have been used during sacred liturgy, because of the highest respect to the holy functions by the altar, those vestments have been used for this purpose only, and no other.

The dalmatic is a long wide-sleeved tunic, which serves as a liturgical vestment in the Roman Catholic Church, used by deacons and bishops. The origins of the dalmatic go back to the Roman times and it came from Dalmatian coast in the II century AD. Once in Rome, it became typical attire of the upper class.

The VI century brought major changes in the contemporary secular clothing; however, those changes did not affect the liturgical vestments. The dalmatic at first became bishops' outfits with the consent of the emperor but Pope Sylvester (3I4-335) ruled for Roman deacons to use the dalmatic while serving during liturgical ministry. Ever since, the chasuble became very popular among clergy, the dalmatic was worn only by deacons.

Originally, simple and white dalmatics were symbols of holy and pure religion as well as the pureness of life of people wearing them. Initially, the dalmatic was used as liturgical vestment. It was a tunic decorated with two vertical stripes on left and right side as well as on the front and back of the garment. Starting in XVI century, the dalmatics were sometimes adorned with elaborate designs.

The current liturgic regulations prescribe dalmatic as a personal garment of a deacon which is being worn only for special liturgical celebrations. Caeremoniale episcoporum indicates that the dalmatics can be used by the bishops especially during ording a priest, the blessing of the abbot or abbess and the blessing of the altar or church. 
4. Uniwersytet Papieski

If: Ji: Jana Pawła II 